\title{
Effects of Concrete Cover on GFRP RC Bridge Deck
}

\author{
Jianwei Huang \\ Southern Illinois University Edwardsville \\ Department of Civil Engineering, SIUE, Edwardsville, IL, USA \\ jiahuan@siue.edu
}

\section{Extended Abstract}

In the United States and Canada, steel reinforced concrete (RC) bridge decks have suffered from steel corrosion due to the enormous use of deicing salts in winter seasons [1,6]. In order to resolve the steel corrosion problem, glass fiber reinforced polymer (GFRP) bars have been extensively researched as a promising substitute to the conventional steel reinforcement [1]. To date, several design specifications $[1,2,3,4,5]$ have been published to guide the proper use of GFRP bars in RC structures, including the AASHTO LFRD design guide specifications for GFRP RC bridge decks [5]. In addition, a number of GFRP RC bridge decks have been built in Canada and the US as demonstration projects, in which $2.5 \mathrm{in}$. and $1.5 \mathrm{in}$. were often used for the top and bottom concrete covers, respectively [e.g., 6]. The use of larger concrete cover could protect the internal GFRP bars in the deck; however, it may increase the cost of the project. Also, considering the excellent corrosion resistance of GFRP bars, the large concrete cover may not be necessary. In this regard, this paper aimed to assess the influence of concrete clear covers on the design and cost of the GFRP RC bridge deck. In order to discover the effects of concrete cover, a comprehensive parametric study was conducted in this research, where the AASHTO LFRD bridge design specifications [7] and LRFD design specifications for GFRP RC decks [5] were used as design guides. Totally six bridge deck profiles were considered with three different girder spacing (i.e., 8ft, 9ft, and 10ft) and two different deck thickness (i.e., 8in. and 9in.). For each bridge deck profile, the top GFRP bars were designed for four different top concrete covers (i.e., 1in., 1.5in., 2in., and 2.5in.); whereas, the bottom GFRP bars were designed for two different bottom concrete covers (i.e., 1in. and 1.5in.). For each case, the bar size and bar spacing were determined for the top and bottom GFRP bars by a complete deck design with meeting the requirements at various limit states (e.g., service limit state, ultimate limit state) as specified in the design specifications [5,7]. The costs of GFRP bars were subsequently computed and normalized for comparisons among the different decks. Research results from this study not only provided a quantitative cost comparison among different concrete covers, but also suggested optimum design parameters for a GFRP $\mathrm{RC}$ bridge deck.

\section{References}

[1] ACI 440.1R-15, "Guide for the Design and Construction of Concrete Reinforced with FRP Bars," American Concrete Institute, Committee 440, Farmington Hills, MI, USA, 2015.

[2] ACI 440.6-08, "Specification for Carbon and Glass Fiber Reinforced Polymer Bar Materials for Concrete Reinforcement," American Concrete Institute, Committee 440, Farmington Hills, MI, USA, 2008.

[3] CSA S806-02, "Design and Construction of Building Components with Fibre-Reinforced Polymers," Canadian Standards Association, Ontario, 2002.

[4] CSA S6-14, "Canadian Highway Bridge Design Code," Canadian Standards Association, Ontario, 2014.

[5] AASHTO LRFD Bridge Design Guide Specifications for GFRP-Reinforced Concrete Bridge Decks and Traffic Railings, the American Association of State Highway and Transportation Officials, Washington DC, USA, 2009.

[6] B. Benmokrane, E. El-Salakawy, A. El-Ragaby, and T. Lackey, "Designing and testing of concrete bridge decks reinforced with glass FRP bars," Journal of Bridge Engineering, vol. 11, no. 2, pp 217-229, 2006.

[7] AASHTO LRFD Bridge Design Specifications, $7^{\text {th }}$ Edition, the American Association of State Highway and Transportation Officials, Washington DC, USA, 2014. 